\title{
Energy efficiency of pasta waste and its effect on performance, carcass, and economic viability of broilers
}

\author{
Ana Carolina Ferreira dos Santos ${ }^{1}$ (iD, Maria do Carmo Mohaupt Marques Ludke ${ }^{2^{*}}$ (D), Jorge \\ Vitor Ludke ${ }^{3}$ iD, Jussiede Silva Santos ${ }^{1}$ iD, Juliane Garlet Viapiana' ${ }^{1}$ iD, Carlos Bôa-Viagem \\ Rabello² $^{\text {iD }}$, Thaysa Rodrigues Torres ${ }^{4}$ iD, Lidiane Rosa Custódio ${ }^{1}$ (iD
}

\footnotetext{
${ }^{1}$ Universidade Federal Rural de Pernambuco, Programa de Pós-graduação em Zootecnia, Recife, PE, Brasil.

${ }^{2}$ Universidade Federal Rural de Pernambuco, Departamento de Zootecnia, Recife, PE, Brasil.

${ }^{3}$ Embrapa Suínos e Aves, Concórdia, SC, Brasil.

${ }^{4}$ Universidade Federal Rural de Pernambuco, Unidade Acadêmica de Serra Talhada, Serra Talhada, PE, Brasil.
}

\begin{abstract}
The objective of this study was to determine the energy value of pasta waste through a metabolism trial and determine the best level of its inclusion in broiler diets. In the metabolism trial, sixty 14-day-old birds were assigned to two treatments (control diet and a diet in which $30 \%$ was replaced by the byproduct) with six replicates and five birds per experimental unit. In the performance trial, 525 one-day-old chicks were assigned to treatments consisting of five levels of pasta waste $\left(0,100,200,300\right.$, and $\left.400 \mathrm{~g} \mathrm{~kg}^{-1}\right)$ in the diet, with seven replicates and 15 birds per experimental unit, in a completely randomized design. The phases of up to 7, 21,35, and 42 days of age were evaluated. At the end, two broilers with average weight were selected per plot for carcass evaluation. An economic analysis was undertaken. The calculated apparent metabolizable energy (AME) value of the waste was $3812 \mathrm{kcal} \mathrm{kg}^{-1}$, and its nitrogen-corrected AME was $3616 \mathrm{kcal} \mathrm{kg}^{-1}$. In the performance trial, no significant difference was detected from 1 to 7 days. However, in the other phases, a decreasing effect was observed on feed intake, weight gain, slaughter weight, hot- and cold-carcass weights, empty- and full-gizzard weights and yields, cuts (chest, drumstick, thigh, wings, and back), and feed conversion worsened. The revenue and gross margin calculated for the diets decreased with pasta waste. Therefore, pasta waste is not a viable alternative, except in the pre-starter phase of broilers.
\end{abstract}

Key Words: birds, gross margin, pasta byproducts, prime cuts, weight gain

\section{Introduction}

Brazil is the fourth largest producer of pastas. In 2017, approximately $1,209,000 \mathrm{t}$ were produced in the country, which ranked only after Italy, the United States, and Russia. This sector involves approximately 80 small, medium, and large companies, which directly employ over 20,000 people. Despite the approximate 500 types and shapes that exist, dry pasta is the most widely consumed version, corresponding to $81.4 \%$ of the total national production (ABIMAPI, 2017).

The pasta manufacture process comprises five steps: mixing, which consists of incorporating the solid (wheat flour and additives) and liquid (water and eggs) ingredients; kneading, usually performed under vacuum to prevent the formation of air bubbles in the dough, which generates

Received: May 8, 2018

Accepted: July 6, 2018

*Corresponding author: maria.mmarques@ufrpe.br

Copyright (C) 2018 Sociedade Brasileira de Zootecnia. This is an Open Access article distributed under the terms of the Creative Commons Attribution License (http://creativecommons.org/licenses/by/4.0/), which permits unrestricted use, distribution, and reproduction in any medium, provided the original work is properly cited. whitish spots on the pasta; shaping; drying, in which predetermined amounts of water are extracted for each type of pasta (dry pastas should have a maximum moisture content of $\left.130 \mathrm{~g} \mathrm{~kg}^{-1}\right)$; and lastly, packaging.

Pasta waste is obtained from the grinding of residues composed of parts that become unsuitable for human consumption due to breakage or inadequate storage and cooking. The amount of pasta wasted by the industry ranges from 47 to $74 \mathrm{~g} \mathrm{~kg}^{-1}$ depending on the type of pasta, which arouses the interest of companies in the environmentally correct disposal of this byproduct (Lopes et al., 2009). In this scenario, the use of industrial pasta waste in animal feeding is a good alternative given its constant availability and stable cost coupled with the inexistent harvest-fluctuation problem (Silva et al., 2014). This ingredient contains values of $119 \mathrm{~g} \mathrm{~kg}^{-1}$ of crude protein (CP) and $3494 \mathrm{kcal} \mathrm{kg}^{-1}$ of nitrogen-corrected apparent metabolizable energy, which are higher than those found in corn (Rostagno et al., 2017). Silva et al. (2012b) found a $\mathrm{CP}$ content of $126.6 \mathrm{~g} \mathrm{~kg}^{-1}$ and essential and non-essential amino acid digestibility coefficients of 0.929 and $0.914 \mathrm{~g} \mathrm{~g}^{-1}$, respectively, in this product. According to the definition of 
the Compêndio Brasileiro de Alimentação Animal (2017), the maximum allowed moisture, ether extract (EE), crude fiber (CF), and mineral matter (MM) values are 130, 40, 30, and $40 \mathrm{~g} \mathrm{~kg}^{-1}$, respectively, and the minimum allowed $\mathrm{CP}$ content is $55 \mathrm{~g} \mathrm{~kg}^{-1}$.

However, research testing this ingredient in the feeding of broilers is still limited. On this basis, the present study was developed to analyze the nutritional and energy values of pasta waste and determine the best inclusion level of this byproduct in diets for broilers considering performance, carcass characteristics, and economic viability.

\section{Material and Methods}

The local Committee of Ethics issued approval number $087 / 2016$ for the research project. It took place in Recife, PE, Brazil ( $8^{\circ} 04^{\prime} 03^{\prime \prime} \mathrm{S}$ and $\left.34^{\circ} 55^{\prime} 00^{\prime \prime} \mathrm{W}\right)$. Two experiments were carried out with male broilers of the Cobb $500^{\circledR}$ strain: one metabolism trial to determine the apparent metabolizable energy (AME) and nitrogen-corrected AME (AMEn) values of pasta residue and another trial to evaluate performance, carcass characteristics, and economic viability.

Corn- and soybean meal-based control diet (Table 1) and a test diet that consisted of control diet containing $300 \mathrm{~g} \mathrm{~kg}^{-1}$ pasta waste composed the two treatments of the metabolism trial. Sixty broilers used in the trial were 14 days old and had an average weight of $481.5 \pm 0.50 \mathrm{~g}$. The trial had six replicates per treatment and five broilers per experimental unit distributed in a completely randomized design.

Table 1 - Chemical composition and nutritional values of control diet used in the metabolism trial

\begin{tabular}{|c|c|c|c|}
\hline \multirow{2}{*}{$\begin{array}{l}\text { Ingredient } \\
\text { Corn }\end{array}$} & \multirow{2}{*}{$\begin{array}{c}\begin{array}{c}\text { Quantity } \\
\left(\mathrm{g} \mathrm{kg}^{-1}\right)\end{array} \\
555.6\end{array}$} & \multicolumn{2}{|c|}{$\begin{array}{c}\text { Nutritional composition }\left(\mathrm{g} \mathrm{kg}^{-1}\right) \\
\text { and energy value }\end{array}$} \\
\hline & & AMEn $\left(\mathrm{kcal} \mathrm{kg}^{-1}\right)$ & 3,050 \\
\hline Soybean meal $45 \%$ & 369.7 & Crude protein & 212.0 \\
\hline Soybean oil & 35.5 & Calcium & 8.4 \\
\hline Dicalcium phosphate & 15.5 & Available phosphorus & 4.0 \\
\hline Limestone & 9.2 & Sodium & 2.1 \\
\hline Common salt & 4.8 & Ether extract & 61.6 \\
\hline L-lysine $\mathrm{HCl} 78.8 \%$ & 2.3 & Crude fiber & 30.0 \\
\hline DL-methionine 99\% & 3.0 & Digestible amino acids & \\
\hline L-threonine $98.5 \%$ & 0.8 & Lysine & 12.17 \\
\hline Vitamin supplement ${ }^{1}$ & 1.5 & Methionine & 5.80 \\
\hline Mineral supplement ${ }^{2}$ & 1.2 & Methionine + cysteine & 8.76 \\
\hline Choline chloride $60 \%$ & 1.0 & Threonine & 7.91 \\
\hline Total & 1000 & Tryptophan & 2.84 \\
\hline
\end{tabular}

AMEn - nitrogen-corrected apparent metabolizable energy.

${ }^{1}$ Guaranteed levels per kg of vitamin supplement: vitamin A, 10,000,000 IU; vitamin D3, 2,000,000 IU; vitamin E, 20,000 mg; vitamin K3, 4,000 mg; vitamin B1, 1,880 mg; vitamin B2, 5,000 mg; vitamin B6, 2,000 mg; vitamin B12, 10,000 mcg; niacin, 30,000 mg; pantothenic acid, $13,500 \mathrm{mg}$; folic acid, $500 \mathrm{mg}$.

${ }^{2}$ Guaranteed levels per kg of mineral supplement: selenium, $360 \mathrm{mg}$; zinc, $110,000 \mathrm{mg}$; iodine, 1,400 mg; copper, 20,000 mg; manganese, 156,000 mg; iron, 96,000 mg; antioxidant, 100,000 $\mathrm{mg}$.
Birds were housed from the first day in metabolism cages $(1.0 \times 0.5 \times 0.5 \mathrm{~m})$ equipped with cup drinkers, trough feeders, and collection trays lined with plastic canvas. The experimental period was eight days, starting at 14 days of age, and consisted of four days of adaptation to diets and facilities and another four days for total excreta collection. Ferric oxide (1\%) was used to mark the start and end of the collection period.

Collections were performed twice daily (morning and afternoon) to prevent the occurrence of fermentation. Samples were packed in labeled plastic bags and were then frozen at $-20{ }^{\circ} \mathrm{C}$. At the end of the experimental period, all excreta were thawed, homogenized, weighed, and pre-dried in a forced-air oven at $55{ }^{\circ} \mathrm{C}$ for $72 \mathrm{~h}$. Excreta were then ground in a ball mill. Representative samples of experimental diets and excreta were taken to the laboratory to determine the dry matter (DM) and CP contents, according to Detmann et al. (2012), and the gross energy (GE) content, following Silva and Queiroz (2002).

Subsequently, equations described by Matterson et al. (1965) were used to determine the apparent metabolization coefficient of dry matter $\left(\mathrm{AMC}_{\mathrm{DM}}\right)$, crude protein $\left(\mathrm{AMC}_{\mathrm{CP}}\right)$, gross energy $\left(\mathrm{AMC}_{\mathrm{GE}}\right)$, and $\mathrm{AME}$ and $\mathrm{AMEn}$.

In the performance trial, 525 chicks aged 1 to 42 days were assigned to five treatments: corn- and soybean mealbased control diet and another four diets formulated with pasta waste inclusion levels $\left(100,200,300\right.$, and $\left.400 \mathrm{~g} \mathrm{~kg}^{-1}\right)$ in a completely randomized design with seven replicates and 15 birds per experimental unit. The mash diets (Tables 2 and 3) were isoenergetic and isoproteic and formulated to meet the nutritional requirements recommended by Rostagno et al (2011). In the diet formulation, the digestibility coefficients of the amino acids of pasta waste described by Silva et al. (2012b) were adopted. These coefficients were applied to the adjusted values of total amino acids (adjustment calculated proportionally to the $\mathrm{CP}$ of the ingredient). The feeding regime consisted of four phases: pre-starter, from the 1st to the 7th day; starter, from the 8th to the 21st day; grower, from the 22 nd to the 35 th day; and finisher, from the 36th to the 42nd day of life. The mash diets and water were available ad libitum.

Samples of pasta waste and experimental diets were analyzed for the concentrations of DM, CP, ether extract (EE), crude fiber (CF), and mineral matter (MM), as proposed by Detmann et al. (2012). Mean geometric diameter (MGD) (Zanotto et al., 2016) and density were also determined. Density was obtained using a glass funnel coupled to a beaker $(50 \mathrm{~mL})$ and a precision scale, in which the weight of samples were measured and then divided by the beaker volume. 
Birds were housed in a masonry shed containing cages with $10 \mathrm{~cm}$ wood shavings bed, equipped with trough feeders and nipple drinkers. A continuous $(24 \mathrm{~h})$ lighting program was adopted throughout the experimental period. At the start and end of each phase, feed leftovers and animals were weighed to determine feed intake, weight gain, and feed conversion.

At the end of the performance trial, two broilers per plot were selected based on their average weight and identified and, after starving, were slaughtered. To evaluate the yields of carcass, cuts, and offal, the selected broilers went through a feed-deprivation period of $6 \mathrm{~h}$ to prevent contaminations during slaughter. After fasting, they were weighed again and subsequently slaughtered. The slaughter consisted of five steps: stunning, bleeding, scalding, plucking, and evisceration. Carcasses (without head, feet, and offal) were weighed to calculate the hot carcass yield. Afterwards, they were placed in labeled plastic bags and taken to a cold room at $5{ }^{\circ} \mathrm{C}$, where they remained for $24 \mathrm{~h}$. After this time, they were taken out of the room and weighed to determine the cold carcass weight. Cuts were extracted and weighed on this occasion. The yields of carcass (hot and cold) and organs (heart, gizzard, liver, and intestine) were determined by relating their weight to the fasted animal weight. The yields of cuts (chest, drumstick, thigh, wings, and back), in turn, were determined relative to the cold carcass weight.

The economic viability of the diets for broilers was determined according to Lana (2000), based on the

Table 2 - Chemical composition and nutritional values of diets used in the pre-starter ( 1 to 7 days) and starter ( 8 to 21 days) phases

\begin{tabular}{|c|c|c|c|c|c|c|c|c|c|c|}
\hline \multirow{3}{*}{ Item } & \multicolumn{10}{|c|}{ Pasta meal level $\left(\mathrm{g} \mathrm{kg}^{-1}\right)$} \\
\hline & \multicolumn{5}{|c|}{1 to 7 days } & \multicolumn{5}{|c|}{8 to 21 days } \\
\hline & 0 & 100 & 200 & 300 & 400 & 0 & 100 & 200 & 300 & 400 \\
\hline \multicolumn{11}{|l|}{ Ingredient $\left(\mathrm{g} \mathrm{kg}^{-1}\right)$} \\
\hline Corn & 545.7 & 464.5 & 383.3 & 302.1 & 208.9 & 570.1 & 489.0 & 407.8 & 326.6 & 245.5 \\
\hline Soybean meal $45 \%$ & 387.5 & 375.1 & 362.8 & 350.4 & 340.2 & 359.0 & 346.5 & 334.3 & 321.9 & 309.5 \\
\hline Pasta meal & 0 & 100 & 200 & 300 & 400 & 0.0 & 100 & 200 & 300 & 400 \\
\hline Soybean oil & 23.7 & 16.7 & 9.8 & 2.8 & 0.0 & 32.5 & 25.5 & 18.6 & 11.6 & 4.7 \\
\hline Dicalcium phosphate & 19.0 & 19.2 & 19.3 & 19.4 & 19.6 & 15.6 & 15.7 & 15.8 & 16.0 & 16.1 \\
\hline Limestone & 9.1 & 9.0 & 8.8 & 8.7 & 8.5 & 9.5 & 9.3 & 9.1 & 9.0 & 8.8 \\
\hline Common salt & 5.1 & 5.1 & 5.1 & 5.1 & 5.1 & 4.9 & 4.9 & 4.9 & 4.9 & 4.9 \\
\hline L-lysine $\mathrm{HCl} 78.8 \%$ & 2.9 & 3.2 & 3.6 & 3.9 & 4.2 & 2.4 & 2.7 & 3.1 & 3.4 & 3.8 \\
\hline DL-methionine $99 \%$ & 3.6 & 3.6 & 3.6 & 3.6 & 3.5 & 3.1 & 3.1 & 3.1 & 3.0 & 3.0 \\
\hline L-threonine $98.5 \%$ & 1.2 & 1.4 & 1.5 & 1.7 & 1.9 & 0.8 & 1.0 & 1.2 & 1.4 & 1.6 \\
\hline Mineral-vitamin supplement ${ }^{1}$ & 1.2 & 1.2 & 1.2 & 1.2 & 1.2 & 1.2 & 1.2 & 1.2 & 1.2 & 1.2 \\
\hline Coccidiostat & 1.0 & 1.0 & 1.0 & 1.0 & 1.0 & 1.0 & 1.0 & 1.0 & 1.0 & 1.0 \\
\hline Inert & 0.0 & 0.0 & 0.0 & 0.0 & 5.9 & 0.0 & 0.0 & 0.0 & 0.0 & 0.0 \\
\hline \multicolumn{11}{|l|}{ Calculated composition $\left(\mathrm{g} \mathrm{kg}^{-1}\right)$} \\
\hline AMEn $\left(\mathrm{kcal} \mathrm{kg}^{-1}\right)$ & 2960 & 2960 & 2960 & 2960 & 2960 & 3050 & 3050 & 3050 & 3050 & 3050 \\
\hline Crude protein & 224.0 & 224.0 & 224.0 & 224.0 & 224.0 & 212.0 & 212.0 & 212.0 & 212.0 & 212.0 \\
\hline Calcium & 9.2 & 9.2 & 9.2 & 9.2 & 9.2 & 8.4 & 8.4 & 8.4 & 8.4 & 8.4 \\
\hline Available P & 4.7 & 4.7 & 4.7 & 4.7 & 4.7 & 4.0 & 4.0 & 4.0 & 4.0 & 4.0 \\
\hline Sodium & 2.2 & 2.2 & 2.2 & 2.2 & 2.2 & 2.1 & 2.1 & 2.1 & 2.1 & 2.1 \\
\hline Ether extract & 50.1 & 41.1 & 32.2 & 23.3 & 18.1 & 59.2 & 50.3 & 41.4 & 32.4 & 23.5 \\
\hline Crude fiber & 30.0 & 29.8 & 29.7 & 29.5 & 29.2 & 28.9 & 28.7 & 28.6 & 28.4 & 28.2 \\
\hline Linoleic acid & 26.7 & 21.7 & 16.7 & 11.8 & 8.9 & 31.6 & 26.7 & 21.7 & 16.7 & 11.7 \\
\hline \multicolumn{11}{|l|}{ Digestible amino acids } \\
\hline Lysine & 13.24 & 13.24 & 13.24 & 13.24 & 13.24 & 12.17 & 12.17 & 12.17 & 12.17 & 12.17 \\
\hline Methionine + cysteine & 9.53 & 9.53 & 9.53 & 9.53 & 9.53 & 8.76 & 8.76 & 8.76 & 8.76 & 8.76 \\
\hline Threonine & 8.61 & 8.61 & 8.61 & 8.61 & 8.61 & 7.91 & 7.91 & 7.91 & 7.91 & 7.91 \\
\hline Tryptophan & 2.52 & 2.52 & 2.52 & 2.52 & 2.52 & 2.37 & 2.37 & 2.37 & 2.37 & 2.37 \\
\hline \multicolumn{11}{|l|}{ Analyzed composition $\left(\mathrm{g} \mathrm{kg}^{-1}\right)$} \\
\hline Dry matter & 885.8 & 881.8 & 884.4 & 883.2 & 883.2 & 884.1 & 885.1 & 887.3 & 882.3 & 884.4 \\
\hline Crude protein & 229.2 & 226.2 & 225.2 & 222.4 & 222.2 & 211.1 & 219.9 & 211.9 & 211.5 & 214.7 \\
\hline Ether extract & 50.4 & 40.2 & 30.7 & 22.8 & 18.2 & 59.0 & 50.3 & 41.2 & 32.2 & 23.2 \\
\hline Crude fiber & 30.5 & 30.0 & 28.1 & 27.2 & 29.0 & 29.3 & 28.5 & 25.9 & 27.3 & 29.8 \\
\hline Ash & 55.8 & 54.9 & 51.1 & 52.6 & 51.6 & 53.9 & 52.4 & 51.5 & 53.4 & 52.6 \\
\hline Total carbohydrates & 664.8 & 678.8 & 692.9 & 702.2 & 708.8 & 676.0 & 677.4 & 695.4 & 702.9 & 709.5 \\
\hline $\operatorname{MGD}(\mu \mathrm{m})$ & 786.4 & 778.3 & 754.9 & 633.1 & 632.0 & 858.7 & 808.0 & 777.8 & 761.0 & 705.7 \\
\hline Density (kg/L) & 0.709 & 0.740 & 0.744 & 0.747 & 0.758 & 0.723 & 0.726 & 0.728 & 0.731 & 0.732 \\
\hline
\end{tabular}

AMEn - nitrogen-corrected apparent metabolizable energy; MGD - mean geometric density.

${ }^{1}$ Guaranteed level per kg of mineral-vitamin supplement: vitamin A, 5,000,000 IU; folic acid, $150 \mathrm{mg}$; pantothenic acid, 8,000 mg; biotin, $40.0 \mathrm{mg}$; niacin, $18.0 \mathrm{~g}$; vitamin B12, 6,500 mcg; vitamin B2, 2,000 mg; vitamin B6, $250 \mathrm{mg}$; vitamin D3, 1,600,000 IU; vitamin K3, 1,000 mg; copper, 1,400 mg; iron, 6,000 mg; iodine, $915 \mathrm{mg}$; manganese, $17.0 \mathrm{~g}$; selenium, $800 \mathrm{mg}$; zinc, $33 \mathrm{~g}$. 
following variables: feed price (1), feeding cost per broiler (2), feeding cost per $\mathrm{kg}$ weight gain (3), gross revenue (4), gross margin per broiler (5), and gross margin per $\mathrm{kg}$ weight gain (6). These variables were obtained by using the following formulae: $\mathrm{FP}=\sum_{k=1}^{n} F_{k} \times P_{k}(1)$, in which FP is the feed price (US\$ $\mathrm{kg}^{-1}$ ) per treatment and production phase, $F_{k}$ is the proportion of the 1,2 , $3, \ldots, \mathrm{n}$ ingredient in the diet of the treatment, and $P_{k}$ is the respective price (US\$ $\mathrm{kg}^{-1}$ ) of the correspondent ingredient; $\mathrm{FC}_{\mathrm{b}}=\mathrm{FI} \times \mathrm{FP}(2)$, in which $\mathrm{FC}_{\mathrm{b}}$ is the feeding cost (US\$ per broiler) calculated per experimental unit within the treatment in the considered production phase, FI is the correspondent feed intake (in $\mathrm{kg}$ per broiler) in each experimental unit within treatment and production phase, and FP is the associated feed price (US\$ $\mathrm{kg}^{-1}$ ) per treatment and production phase; $\mathrm{FC}_{\mathrm{kg}}=\mathrm{F}: \mathrm{G}$ ratio $\times \mathrm{FP}(3)$, in which $\mathrm{FC}_{\mathrm{kg}}$ is the feeding cost per $\mathrm{kg}$ weight gain (US\$ kg ${ }^{-1}$ weight gain) per experimental unit within treatment in the considered production phase, $\mathrm{F}: \mathrm{G}$ ratio is the correspondent feed conversion per experimental unit within the treatment in the considered production phase, and $\mathrm{FP}$ is the associated feed price per treatment and production phase; $\mathrm{GR}=\mathrm{BP}_{\mathrm{kg}} \times \mathrm{WG}$ (4), in which $\mathrm{GR}$ is the gross revenue (US\$ per broiler) in the experimental unit within treatment for the considered production phase, $\mathrm{BP}_{\mathrm{kg}}$ is the broiler price (US\$ per $\mathrm{kg}$ ), and WG is the associated weight gain evaluated per experimental unit within the treatment in the considered production phase; $\mathrm{GM}_{\mathrm{b}}=\mathrm{GR}-$ $\mathrm{FC}_{\mathrm{b}}(5)$, in which $\mathrm{GM}_{\mathrm{b}}$ is the gross margin (US\$ per broiler) in the experimental unit within treatment in the considered

Table 3 - Chemical composition and nutritional values of diets used in the grower (22 to 35 days) and finisher ( 36 to 42 days) phases

\begin{tabular}{|c|c|c|c|c|c|c|c|c|c|c|}
\hline \multirow{3}{*}{ Item } & \multicolumn{10}{|c|}{ Pasta meal inclusion level $\left(\mathrm{g} \mathrm{kg}^{-1}\right)$} \\
\hline & \multicolumn{5}{|c|}{22 to 35 days } & \multicolumn{5}{|c|}{36 to 42 days } \\
\hline & 0 & 100 & 200 & 300 & 400 & 0 & 100 & 200 & 300 & 400 \\
\hline \multicolumn{11}{|l|}{ Ingredient $\left(\mathrm{g} \mathrm{kg}^{-1}\right)$} \\
\hline Corn & 600.0 & 518.9 & 437.7 & 356.5 & 275.5 & 642.7 & 561.5 & 480.3 & 399.1 & 317.9 \\
\hline Soybean meal 45\% & 323.2 & 310.8 & 298.5 & 286.1 & 273.7 & 284.5 & 272.1 & 259.7 & 247.3 & 235.0 \\
\hline Pasta meal & 0.0 & 100 & 200 & 300 & 400 & 0.0 & 100 & 200 & 300 & 400 \\
\hline Soybean oil & 41.7 & 34.7 & 27.8 & 20.8 & 13.9 & 40.9 & 33.9 & 27.0 & 20.0 & 13.1 \\
\hline Dicalcium phosphate & 13.3 & 13.5 & 13.6 & 13.8 & 13.9 & 11.2 & 11.4 & 11.5 & 11.7 & 11.8 \\
\hline Limestone & 8.9 & 8.7 & 8.6 & 8.4 & 8.3 & 8.0 & 7.8 & 7.6 & 7.5 & 7.3 \\
\hline Common salt & 4.6 & 4.6 & 4.6 & 4.6 & 4.6 & 4.5 & 4.5 & 4.5 & 4.5 & 4.5 \\
\hline L-lysine $\mathrm{HCl} 78.8 \%$ & 2.4 & 2.7 & 3.1 & 3.4 & 3.8 & 2.7 & 3.0 & 3.3 & 3.7 & 4.0 \\
\hline DL-methionine $99 \%$ & 2.9 & 2.9 & 2.9 & 2.8 & 2.8 & 2.7 & 2.7 & 2.7 & 2.6 & 2.6 \\
\hline L-threonine $98.5 \%$ & 0.7 & 0.9 & 1.1 & 1.3 & 1.5 & 0.8 & 1.0 & 1.1 & 1.3 & 1.5 \\
\hline Mineral-vitamin supplemment ${ }^{1}$ & 1.2 & 1.2 & 1.2 & 1.2 & 1.2 & 1.2 & 1.2 & 1.2 & 1.2 & 1.2 \\
\hline Coccidiostat & 1.0 & 1.0 & 1.0 & 1.0 & 1.0 & 1.0 & 1.0 & 1.0 & 1.0 & 1.0 \\
\hline \multicolumn{11}{|l|}{ Calculated composition $\left(\mathrm{g} \mathrm{kg}^{-1}\right)$} \\
\hline AMEn $\left(\mathrm{kcal} \mathrm{kg}^{-1}\right)$ & 3150 & 3150 & 3150 & 3150 & 3150 & 3200 & 3200 & 3200 & 3200 & 3200 \\
\hline Crude protein & 198.0 & 198.0 & 198.0 & 198.0 & 198.0 & 184.0 & 184.0 & 184.0 & 184.0 & 184.0 \\
\hline Calcium & 7.6 & 7.6 & 7.6 & 7.6 & 7.6 & 6.6 & 6.6 & 6.6 & 6.6 & 6.6 \\
\hline Available P & 3.5 & 3.5 & 3.5 & 3.5 & 3.5 & 3.1 & 3.1 & 3.1 & 3.1 & 3.1 \\
\hline Sodium & 2.0 & 2.0 & 2.0 & 2.0 & 2.0 & 2.0 & 2.0 & 2.0 & 2.0 & 2.0 \\
\hline Ether extract & 68.9 & 59.9 & 51.0 & 42.1 & 33.2 & 69.0 & 60.1 & 51.1 & 42.2 & 33.3 \\
\hline Crude fiber & 27.5 & 27.4 & 27.2 & 27.0 & 26.9 & 26.2 & 26.0 & 25.9 & 25.7 & 25.6 \\
\hline Linoleic acid & 36.8 & 31.9 & 26.9 & 21.9 & 16.9 & 37.1 & 32.1 & 27.1 & 22.1 & 17.1 \\
\hline \multicolumn{11}{|l|}{ Digestible amino acids } \\
\hline Lysine & 11.31 & 11.31 & 11.31 & 11.31 & 11.31 & 10.6 & 10.6 & 10.6 & 10.6 & 10.6 \\
\hline Methionine + cysteine & 8.26 & 8.26 & 8.26 & 8.26 & 8.26 & 7.74 & 7.74 & 7.74 & 7.74 & 7.74 \\
\hline Threonine & 7.35 & 7.35 & 7.35 & 7.35 & 7.35 & 6.89 & 6.89 & 6.89 & 6.89 & 6.89 \\
\hline Tryptophan & 2.18 & 2.18 & 2.18 & 2.18 & 2.18 & 1.97 & 1.97 & 1.97 & 1.97 & 1.97 \\
\hline \multicolumn{11}{|l|}{ Analyzed composition $\left(\mathrm{g} \mathrm{kg}^{-1}\right)$} \\
\hline Dry matter & 886.7 & 886.3 & 885.6 & 882.6 & 882.6 & 882.6 & 886.7 & 888.0 & 886.3 & 884.8 \\
\hline Crude protein & 197.4 & 196.4 & 195.6 & 198.6 & 199.1 & 186.3 & 186.5 & 184.4 & 183.0 & 185.7 \\
\hline Ether extract & 68.8 & 59.6 & 51.2 & 42.2 & 33.4 & 68.5 & 60.6 & 51.1 & 42.2 & 33.6 \\
\hline Crude fiber & 27.1 & 26.6 & 27.1 & 27.6 & 26.5 & 27.5 & 29.7 & 26.6 & 24.3 & 24.1 \\
\hline Ash & 43.3 & 45.1 & 42.9 & 42.7 & 41.9 & 43.6 & 42.0 & 40.6 & 40.3 & 44.0 \\
\hline Total carbohydrates & 690.5 & 699.0 & 710.2 & 716.5 & 725.7 & 701.6 & 710.9 & 723.9 & 734.5 & 736.7 \\
\hline $\operatorname{MGD}(\mu \mathrm{m})$ & 878.4 & 807.3 & 783.1 & 765.8 & 705.2 & 882.8 & 806.6 & 783.4 & 765.5 & 761.6 \\
\hline Density (kg/L) & 0.714 & 0.724 & 0.730 & 0.731 & 0.733 & 0.721 & 0.724 & 0.726 & 0.730 & 0.733 \\
\hline
\end{tabular}

AMEn - nitrogen-corrected apparent metabolizable energy; MGD - mean geometric density.

${ }^{1}$ Guaranteed levels per kg of mineral-vitamin supplement: vitamin A, 5,000,000 IU; folic acid, $150 \mathrm{mg}$; pantothenic acid, $8,000 \mathrm{mg}$; biotin, $40.0 \mathrm{mg}$; niacin, $18.0 \mathrm{~g}$; vitamin B12, 6,500 mcg; vitamin B2, 2,000 mg; vitamin B6, $250 \mathrm{mg}$; vitamin D3, 1,600,000 IU; vitamin K3, 1,000 mg; copper, 1,400 mg; iron, 6,000 mg; iodine, 915 mg; manganese, 17.0 g; selenium, $800 \mathrm{mg}$; zinc, $33 \mathrm{~g}$. 
production phase, GR is the correspondent gross revenue per broiler associated to the experimental unit, and $\mathrm{FC}_{\mathrm{b}}$ is the calculated feeding cost per broiler related to the experimental unit; and $\mathrm{GM}_{\mathrm{kg}}=\mathrm{BP}_{\mathrm{kg}}-\mathrm{FC}_{\mathrm{kg}}$ (6), in which $\mathrm{GM}_{\mathrm{kg}}$ is the gross margin per kg of weight gain (US\$ per kg) in the experimental unit within treatment in the considered production phase, $\mathrm{BP}_{\mathrm{kg}}$ is the broiler price (US\$ per $\mathrm{kg}$ ), and $\mathrm{FC}_{\mathrm{kg}}$ is the feeding cost per $\mathrm{kg}$ weight gain (US\$ $\mathrm{kg}^{-1}$ weight gain) per experimental unit within treatment in the considered production phase. The following prices of each ingredient (US $\$ \mathrm{gg}^{-1}$ ) were considered to calculate the feed costs: pasta meal, 0.13 ; oil, 1.02; limestone, 0.06 ; dicalcium phosphate, 1.06; mineral-vitamin premix, 3.83; salt, 0.77; DL-methionine, 8.25; L-lysine, 2.55; threonine, 2.38; and coccidiostat, 2.93. The adopted broiler price was 1 US\$ per $\mathrm{kg}$ live weight.

The evaluated parameters were subjected to statistical analyze and performed through SAS software (Statistical Analysis System, version 9.2) using the GLM procedure for analysis of variance with employment of the $F$ test and $\alpha$ value at 0.05 .

The statistical model used was:

$$
\mathrm{y}_{\mathrm{ik}}=\mu+\mathrm{T}_{\mathrm{i}}+\varepsilon_{\mathrm{ik}},
$$

in which $\mathrm{y}=$ variables of performance, carcass evaluation, and economic analysis; $\mu=$ overall mean; $\mathrm{T}_{\mathrm{i}}=$ effect of the $i$-th level of pasta waste; and $\varepsilon_{\mathrm{ik}}=$ random error normally distributed with zero mean and variance $\sigma^{2}\left[\varepsilon_{\mathrm{ik}} \sim \mathrm{N}\left(0, \sigma^{2}\right)\right]$.

The detailing of the treatment effect was performed through regression analyses using PROC GENMOD (evaluating linear, quadratic, or cubic effects) and PROC NLMIXED for the Linear Plateau model to determine the best pasta waste inclusion level. The models were compared using the Akaike's information criterion (AIC) considering $\log$ maximum likelihood $(-2 \log \mathrm{L})$ and number of explanatory variables present in the model. Lower AIC values indicate a better model fit to the original data. The linear model is defined as $E(Y)=\alpha+\beta x$ and the Linear Plateau is defined as

$$
E(Y)=\left\{\begin{array}{c}
\alpha+\beta x \text { if } x \leq x_{0} \\
\theta \text { if } x>x_{0}
\end{array} \text { or } E(Y)=\left\{\begin{array}{c}
\alpha+\beta x \text { if } x>x_{0}, \\
\theta \text { if } x \leq x_{0}
\end{array},\right.\right.
$$

in which $E(Y)$ is the expected value of dependent variable, $x$ is the dietary pasta waste concentration, $\theta$ is the value at the plateau, $\alpha$ is the intercept, $\beta$ is the slope, and $x_{0}$ is the pasta waste concentration at the break point.

\section{Results}

The nutritional composition of pasta waste used in this study was $888.7 \mathrm{~g} \mathrm{~kg}^{-1} \mathrm{DM}, 115.5 \mathrm{~g} \mathrm{~kg}^{-1} \mathrm{CP}, 9.2 \mathrm{~g} \mathrm{~kg}^{-1} \mathrm{EE}$, $13.0 \mathrm{~g} \mathrm{~kg}^{-1} \mathrm{CF}, 7.4 \mathrm{~g} \mathrm{~kg}^{-1} \mathrm{MM}$, and $3882 \mathrm{kcal} \mathrm{kg}^{-1} \mathrm{GE}$. The non-nitrogen extract (NNE) value calculated by difference was $743.6 \mathrm{~g} \mathrm{~kg}^{-1}$. Density and MGD were $0.8693 \mathrm{~g} / \mathrm{mL}$ and $677 \mu \mathrm{m}$, respectively. The apparent metabolizability coefficients of DM, CP, and GE and AME and AMEn values were $0.6705 \mathrm{~g} \mathrm{~g}^{-1}, 0.6503 \mathrm{~g} \mathrm{~g}^{-1}, 0.8152 \mathrm{~g} \mathrm{~g}^{-1}, 3812 \mathrm{kcal} \mathrm{kg}^{-1}$, and $3616 \mathrm{kcal} \mathrm{kg}^{-1}$, respectively.

In the pre-starter phase, no significant differences were observed for weight gain, feed intake, or feed conversion (Table 4). Thus, the pasta waste can be used at up to $400 \mathrm{~g} \mathrm{~kg}^{-1}$ in this life stage. However, regardless of the adopted treatment, feed conversion values for this stage were high.

In the period of 8 to 21 days, there was a linear decrease (Table 5) in weight gain and final weight at 21 days and a linear-plateau effect for feed conversion, which showed a constant value up to the maximum inclusion level of $170 \mathrm{~g} \mathrm{~kg}^{-1}$ and worsened after that level. In the accumulated period of 1 to 21 days, feed intake did not show significant differences, but weight gain decreased linearly and feed conversion rose (worsened) linearly.

In the period of 22 to 35 days, the inclusion of pasta waste led to a linear decrease in weight gain and final weight at 35 days. A linear-plateau effect was detected on feed intake, which decreased linearly, reaching its minimum value at the inclusion level of $212.5 \mathrm{~g} \mathrm{~kg}^{-1}$ and remaining constant and low thereafter. A linear-plateau effect was also seen for feed conversion, whose value remained constant up to the inclusion level of $174.2 \mathrm{~g} \mathrm{~kg}^{-1}$ and worsened linearly afterwards. In the accumulated period of 1 to 35 days, weight gain decreased linearly, whereas non-linear effects were found for feed intake and feed conversion. Feed intake fitted a linear-plateau equation, decreasing linearly up to the level of $221.4 \mathrm{~g} \mathrm{~kg}^{-1}$ and showing a constant minimum value (plateau) afterwards. Agreeing with feed intake, a constant minimum value (plateau) was observed for feed conversion up to the inclusion level of $189.2 \mathrm{~g} \mathrm{~kg}^{-1}$, followed by an estimated increasing (worsening) linear effect.

In the final stage (36 to 42 days), a decreasing linear effect was observed on weight gain, feed intake, and weight at 42 days. For feed conversion, a linear-plateau effect was detected with a linear worsening response occurring up to the inclusion level of $173.8 \mathrm{~g} \mathrm{~kg}^{-1}$ and a subsequent constant high value. In the accumulated period of 1 to 42 days, regression analysis showed a linear increase for feed conversion and a linear decrease for weight gain. For feed intake, however, a linear-plateau effect was observed, with a linear decrease up to the inclusion level of $285.5 \mathrm{~g} \mathrm{~kg}^{-1}$ followed by an estimated constant low value. 
Pasta inclusion in the diets led to a decrease in weights of slaughter weight, hot and cold carcass, and cuts (Table 6). In the analysis of cut weights, a linear decrease was found for chest, drumstick, thigh, wings, and back (Table 7). Among the offal, no significant differences were observed for the weights of heart, liver, and intestine or their respective yields. However, the weights of full and empty gizzard decreased linearly. A linear-plateau effect was also observed for the yield of full gizzard, whose lowest value was found at the pasta inclusion level of $144.9 \mathrm{~g} \mathrm{~kg}^{-1}$. The same was true for the empty-gizzard yield, whose lowest value occurred at the byproduct inclusion level of $200 \mathrm{~g} \mathrm{~kg}^{-1}$.

Treatments affected the economical parameters (Table 8). Feeding costs expressed as US\$ per thousand broilers in the periods displayed linear-plateau effects (Table 9) from 1 to 21 days with the lowest cost at $381.2 \mathrm{~g} \mathrm{~kg}^{-1}$ inclusion, and from 1 to 35 days with the lowest cost at $337.6 \mathrm{~g} \mathrm{~kg}^{-1}$ inclusion. From 1 to 21 days, a linear-plateau effect was detected with the lowest feeding cost occurring at $360.6 \mathrm{~g} \mathrm{~kg}^{-1}$ inclusion of pasta waste. Consequently, the feeding cost in US\$ per thousand $\mathrm{kg}$ of weight gain presented the same linear-plateau effect for the periods, with the lowest values obtained at the inclusion levels of $296.4 \mathrm{~g} \mathrm{~kg}^{-1}$ (1 to 21 days), $253.3 \mathrm{~g} \mathrm{~kg}^{-1}$ (1 to 35 days), and $348.5 \mathrm{~g} \mathrm{~kg}^{-1}$ (1 to 42 days). For the variable gross margin (US\$ per thousand broilers) no significant effect was detected for the period of 1 to 21 days of age. However, a linear-plateau effect was seen from 1 to 35 days with lowest margin found at the pasta waste inclusion level of $228.5 \mathrm{~g} \mathrm{~kg}^{-1}$ of the diet and at 1 to 42 days, whose lowest margin occurred at the inclusion level of $30.6 \mathrm{~g} \mathrm{~kg}^{-1}$. Gross margin, when expressed as US\$ per thousand $\mathrm{kg}$ of weight gain, also showed a linear-plateau effect in the evaluated periods. In the accumulated periods of 1 to 21 days, 1 to 35 days, and 1 to 42 days, the highest gross margins were observed, respectively, at the waste inclusion levels of 296.4 ,

Table 4 - Mean values of performance of broilers fed diets with increasing levels of pasta meal

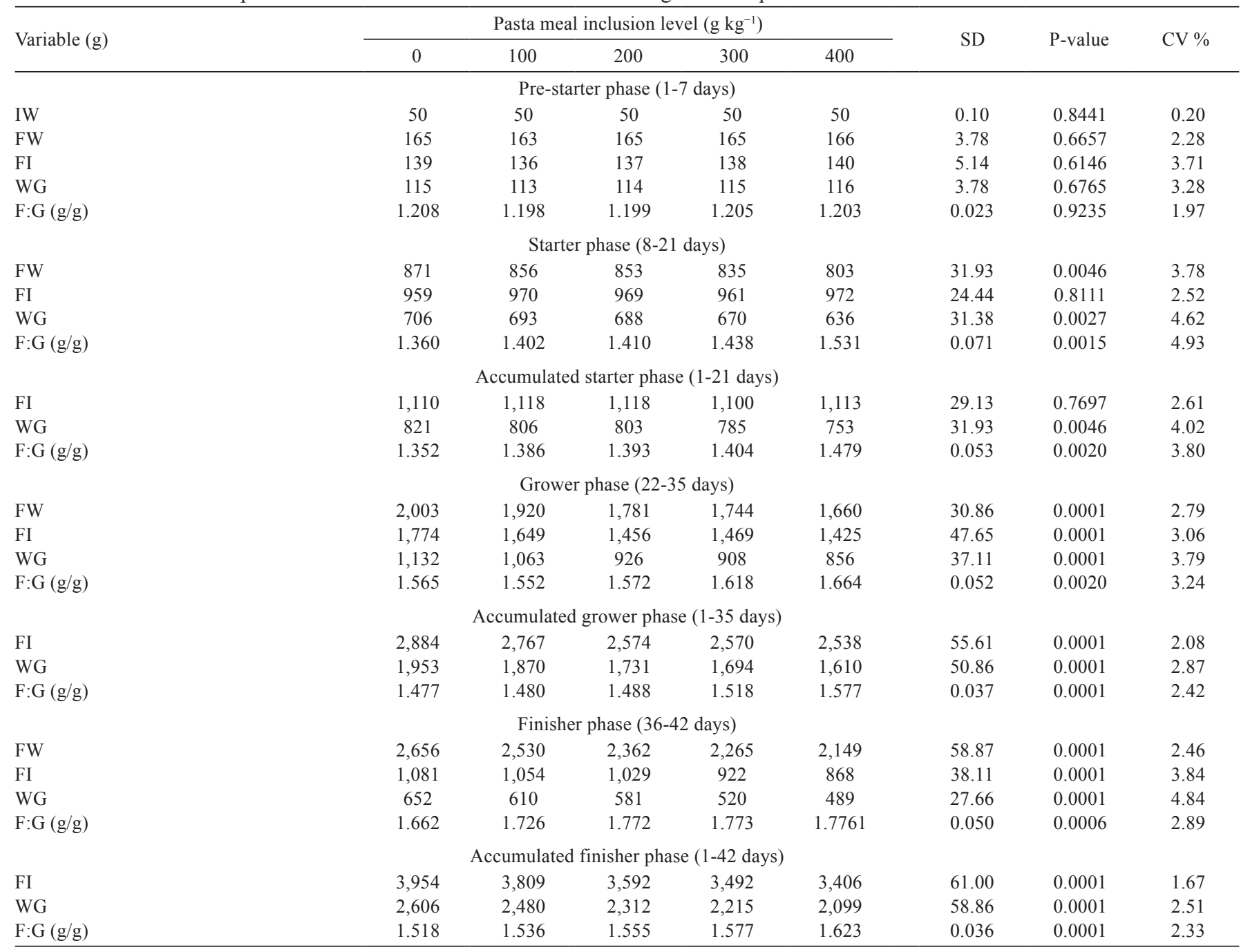

IW - initial weight; FW - final weight; FI - feed intake; WG - weight gain; F:G - feed to gain ratio; SD - standard deviation; CV - coefficient of variation. 
253.3 , and $348.5 \mathrm{~g} \mathrm{~kg}^{-1}$. As shown by regression analysis, gross revenue decreased linearly in the accumulated periods of 1 to 21 days, 1 to 35 days, and 1 to 42 days.

\section{Discussion}

The composition of the pasta waste evaluated here (spaghetti type) included values similar to those presented in the Brazilian Tables by Rostagno et al. (2017). Lima et al. (2012), on the other hand, evaluated the composition of instant noodles and found higher EE (154.8 $\left.\mathrm{g} \mathrm{kg}^{-1}\right)$, GE (4617 kcal kg-1), and AMEn (4256 kcal kg-1) levels when the feedstuff was given to chicks in the pre-starter phase. This finding is explained by the deep-frying step with oil to which instant noodles are subjected (Leoro, 2011). Gezeljeh (2008) determined an AMEn value of $3766 \mathrm{kcal} \mathrm{kg}^{-1}$ in pasta waste containing $70 \mathrm{~g} \mathrm{~kg}^{-1} \mathrm{EE}$ in the evaluation of adult roosters. The AMEn value of pasta waste $\left(3616 \mathrm{kcal} \mathrm{kg}^{-1}\right)$ in the present study was higher than those of the corn (3364 $\left.\mathrm{kcal} \mathrm{kg}^{-1}\right)$ and pasta waste
(3494 $\mathrm{kcal} \mathrm{kg}^{-1}$ ) presented in the table of Rostagno et al. (2017). However, the $\mathrm{AMC}_{\mathrm{GE}}$ of 0.8152 in the present experiment is lower than that calculated (0.9052) from the data given in the table by those authors and cited in the report of Silva et al. (2012a). This contrasts with the lower MM and CF values $\left(8.1 \times 10.0\right.$ and $\left.13.0 \times 18.8 \mathrm{~g} \mathrm{~kg}^{-1}\right)$ and higher NNE and DM values $\left(743.6 \times 729\right.$ and $\left.888.7 \times 885 \mathrm{~g} \mathrm{~kg}^{-1}\right)$ in the present evaluated waste when compared with tabulated values. Because of the different methodologies adopted, there is no direct equivalence between the standardized ileal digestibility values of the nutrients expressed in the tables of Rostagno et al. (2017) and the determinations made in the current metabolism trial. However, the calculated values indicate that the nutritional quality of the pasta waste evaluated here is inferior to that of the waste that originated the tabulated values. The tabulated digestibility coefficient of NNE $\left(0.980 \mathrm{~g} \mathrm{~g}^{-1}\right)$ indicates mainly high availability of carbohydrates, which conflicts with the low $\mathrm{AMC}_{\mathrm{DM}}$ value $\left(0.6705 \mathrm{~g} \mathrm{~g}^{-1}\right)$ calculated in the present research. Another difference is found in the standardized ileal digestibility of

Table 5 - Regression equations of production-performance variables

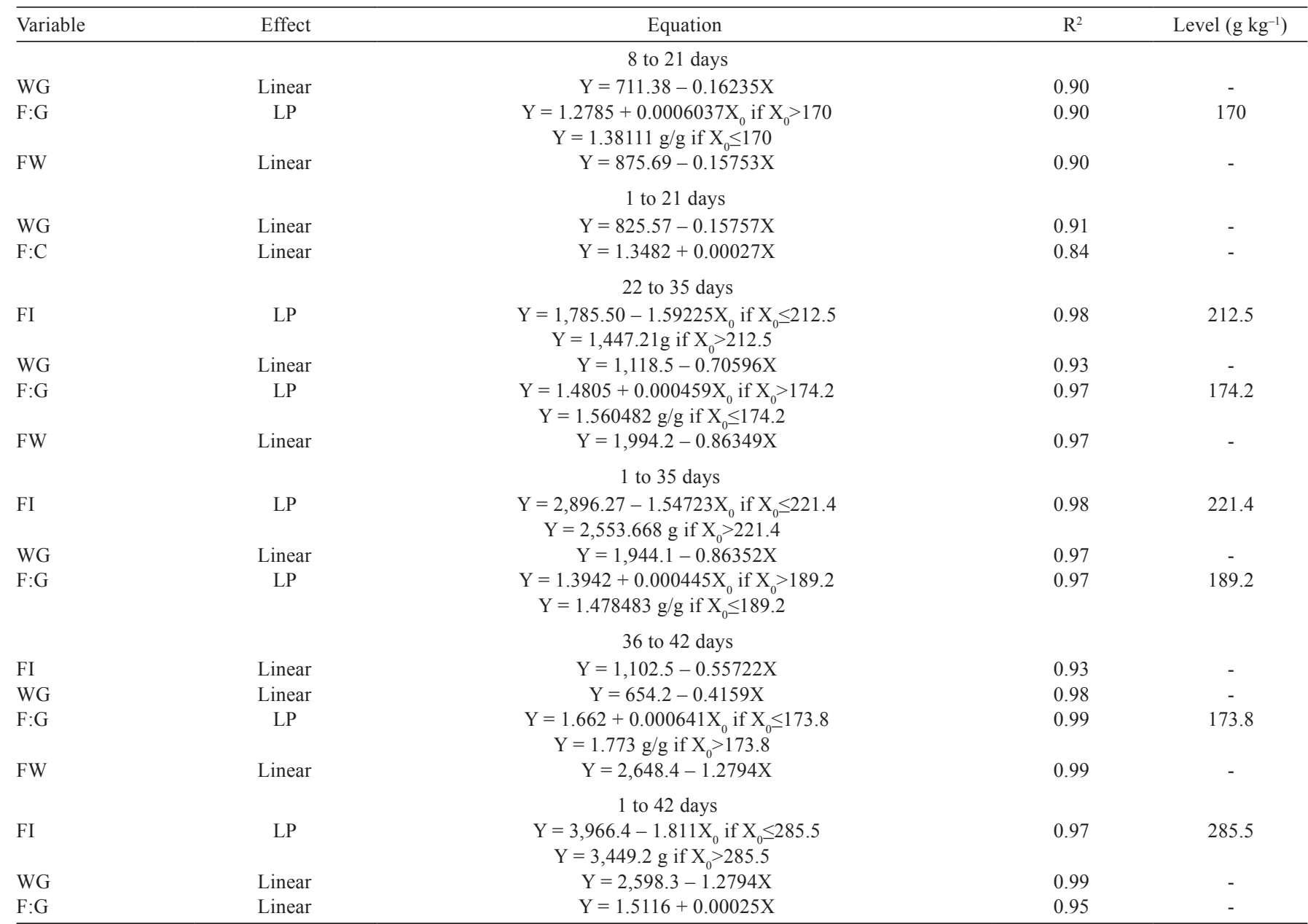

WG - weight gain; F:G - feed-to-gain ratio; FW - final weight; FI - feed intake; LP - linear plateau; $\mathrm{R}^{2}$ - coefficient of determination. 
protein, whose tabulated value was $0.901 \mathrm{~g} \mathrm{~g}^{-1}$, indicating a product of higher quality. In comparison with the results published by Silva et al. (2012b), the amino acid digestibility values of pasta waste were equivalent to the tabulated values of soybean meal. However, in the present study, the $\mathrm{AMC}_{\mathrm{CP}}$ of $0.6503 \mathrm{~g} \mathrm{~g}^{-1}$ is low and indicates that the manufacturing process of the evaluated pasta involved adverse conditions, favoring Maillard reactions. Thermal processing likely markedly influenced the apparent metabolization of carbohydrates and amino acids in the waste, which contributed to the low $\mathrm{AMC}_{\mathrm{DM}}$ and $\mathrm{AMC}_{\mathrm{CP}}$ values. According to Dexter et al. (1984), the protein solubility in $0.05 \mathrm{M}$ acetic acid solution is an indicator of protein denaturation due to the effect of temperature during the production of spaghetti.

Performance results obtained in the pre-starter phase corroborate those published by Paes et al. (2015), who did not find differences for the variables weight gain, feed intake, or feed conversion. Although the linoleic acid requirement of $10.9 \mathrm{~g} \mathrm{~kg}^{-1}$ in this phase was not met by the inclusion of $400 \mathrm{~g} \mathrm{~kg}^{-1}$ pasta waste $\left(8.9 \mathrm{~g} \mathrm{~kg}^{-1}\right)$ in the present experiment, the animals did not have their performance reduced, likely due to the use of nutrients from the yolk sac until the third day of life. However, the pasta waste had a higher EE value than that tabulated by Rostagno et al. (2017), and in each of the oil sources most commonly used in the making of pasta, at least half of the fatty acid concentration corresponds to linoleic acid. Pasta waste naturally does not have antinutritional factors, and the negative effect seen on poultry performance from the eighth day of life is a consequence of inadequate conditions in its manufacturing process. Unlike what was observed in the present study, the literature recommends that pasta waste be used in broiler diets partially replacing corn, with diets including 160 to $240 \mathrm{~g} \mathrm{~kg}^{-1}$ pasta waste, according to Gheisari et al. (2003), or fully replacing corn, with diets including up to $480 \mathrm{~g} \mathrm{~kg}^{-1}$ pasta waste, according to Omole et al. (2013). Rostagno et al. (2017) suggested this ingredient should be used at 100 to $150 \mathrm{~g} \mathrm{~kg}^{-1}$ in the starter phase and at 120 to

Table 6 - Mean values of carcass characteristics of broilers fed diets with increasing levels of pasta meal

\begin{tabular}{|c|c|c|c|c|c|c|c|c|}
\hline \multirow{2}{*}{ Variable } & \multicolumn{5}{|c|}{ Pasta meal inclusion level $\left(\mathrm{g} \mathrm{kg}^{-1}\right)$} & \multirow{2}{*}{$\mathrm{SD}$} & \multirow{2}{*}{ P-value } & \multirow{2}{*}{$\mathrm{CV} \%$} \\
\hline & 0 & 100 & 200 & 300 & 400 & & & \\
\hline \multicolumn{9}{|c|}{ Carcass weights (g) } \\
\hline Fasting weight & 2,600 & 2,522 & 2,421 & 2,325 & 2,148 & 213.8 & 0.0042 & 8.89 \\
\hline Hot carcass & 1,973 & 1,917 & 1,856 & 1,790 & 1,652 & 166.0 & 0.0112 & 9.03 \\
\hline Cold carcass & 1,958 & 1,904 & 1,838 & 1,762 & 1,637 & 163.4 & 0.0086 & 8.98 \\
\hline \multicolumn{9}{|l|}{ Carcass yields (\%) } \\
\hline Hot carcass & 75.84 & 76.07 & 76.65 & 76.95 & 76.98 & 1.87 & 0.7364 & 2.53 \\
\hline Cold carcass & 75.28 & 75.53 & 75.92 & 75.77 & 76.30 & 2.13 & 0.9190 & 2.81 \\
\hline \multicolumn{9}{|l|}{ Cut weights (g) } \\
\hline Chest & 763.3 & 748.1 & 730.5 & 712.7 & 635.8 & 79.8 & 0.0485 & 11.11 \\
\hline Drumsticks & 249.2 & 248.5 & 236.1 & 216.8 & 200.9 & 23.4 & 0.0017 & 10.18 \\
\hline Thighs & 295.7 & 288.8 & 279.1 & 262.7 & 234.1 & 22.5 & 0.0002 & 8.43 \\
\hline Wings & 188.7 & 180.7 & 177.2 & 170.7 & 163.3 & 13.1 & 0.0124 & 7.41 \\
\hline Back & 464.2 & 439.2 & 417.9 & 385.0 & 376.2 & 48.1 & 0.0092 & 11.54 \\
\hline \multicolumn{9}{|l|}{ Cut yields (\%) } \\
\hline Chest & 38.94 & 39.29 & 39.71 & 40.39 & 38.81 & 1.78 & 0.4751 & 4.52 \\
\hline Drumsticks & 12.89 & 13.03 & 12.85 & 12.37 & 12.33 & 0.74 & 0.3394 & 6.22 \\
\hline Thighs & 15.16 & 15.16 & 15.16 & 14.95 & 14.37 & 0.95 & 0.4786 & 6.38 \\
\hline Wings & 9.66 & 9.51 & 9.66 & 9.75 & 10.01 & 0.49 & 0.4258 & 5.07 \\
\hline Back & 23.67 & 23.08 & 22.78 & 21.79 & 23.03 & 1.45 & 0.2061 & 6.34 \\
\hline \multicolumn{9}{|l|}{ Offal weight (g) } \\
\hline Heart & 11.73 & 11.21 & 10.26 & 10.16 & 10.14 & 1.53 & 0.2046 & 14.31 \\
\hline Liver & 51.84 & 52.79 & 48.97 & 45.67 & 48.16 & 6.69 & 0.2952 & 13.52 \\
\hline Full gizzard & 55.90 & 49.00 & 44.62 & 43.06 & 39.06 & 6.64 & 0.0006 & 14.32 \\
\hline Empty gizzard & 42.46 & 37.89 & 32.37 & 32.28 & 28.54 & 5.17 & 0.0002 & 14.89 \\
\hline Intestine & 95.55 & 93.87 & 85.79 & 83.40 & 84.74 & 12.77 & 0.2749 & 14.40 \\
\hline Abdominal fat & 41.42 & 46.67 & 43.43 & 40.77 & 37.85 & 9.42 & 0.5075 & 22.41 \\
\hline \multicolumn{9}{|l|}{ Offal yield (\%) } \\
\hline Heart & 0.45 & 0.44 & 0.42 & 0.44 & 0.47 & 0.04 & 0.2393 & 9.01 \\
\hline Liver & 1.99 & 2.08 & 2.02 & 1.97 & 2.24 & 0.19 & 0.6980 & 9.02 \\
\hline Full gizzard & 2.15 & 1.93 & 1.84 & 1.83 & 1.82 & 0.22 & 0.0553 & 11.69 \\
\hline Empty gizzard & 1.63 & 1.49 & 1.39 & 1.35 & 1.33 & 0.12 & 0.0085 & 11.62 \\
\hline Intestine & 3.67 & 3.71 & 3.53 & 3.60 & 3.94 & 0.35 & 0.2749 & 14.40 \\
\hline Abdominal fat & 1.63 & 1.86 & 1.79 & 1.77 & 1.76 & 0.43 & 0.8985 & 24.44 \\
\hline
\end{tabular}

$\mathrm{SD}$ - standard deviation; CV - coefficient of variation. 
$200 \mathrm{~g} \mathrm{~kg}^{-1}$ in the grower phase. Only Baghbanzhafar et al. (2013) suggested a maximum $100 \mathrm{~g} \mathrm{~kg}^{-1}$ inclusion limit in diets, claiming that high temperatures in pasta production may result in reduced protein utilization, which could compromise the quality of the byproduct. Given the low $\mathrm{AMC}_{\mathrm{CP}}$ value in the present research, the digestible amino acids (mostly lysine and threonine) in the diets containing pasta waste might have been overestimated, and this might have affected the animal performance. Noni and Pagani (2010) described an unavailability potential of lysine of up to $50 \%$ through the formation of insoluble complexes (furosine, epsilon-pyrrole-lysine, and glycosylisomaltol) resulting from application of high temperatures in pasta production.

Additionally, factors associated with processing (grinding) in the feed mill and the physical characteristics of the mash diet (particle size and density) may also have an influence. During the grower and finisher phases, in this study, birds receiving the diets with a smaller particle size, which included pasta waste, ate less. This finding

Table 7 - Regression equations of carcass variables

\begin{tabular}{|c|c|c|c|c|}
\hline Variable (g) & Effect & Equation & $\mathrm{R}^{2}$ & Level $\left(\mathrm{g} \mathrm{kg}^{-1}\right)$ \\
\hline \multicolumn{5}{|l|}{ Carcass weight (g) } \\
\hline Fasting weight & Linear & $\mathrm{Y}=2,623.8-1.1021 \mathrm{X}$ & 0.97 & - \\
\hline Hot carcass & Linear & $Y=1,991.28-0.76928 X$ & 0.95 & - \\
\hline \multicolumn{5}{|l|}{ Cut weights (g) } \\
\hline Chest & Linear & $Y=776.1402-0.2901950 X$ & 0.85 & - \\
\hline Drumsticks & Linear & $\mathrm{Y}=255.9383-0.12820 \mathrm{X}$ & 0.93 & - \\
\hline Back & Linear & $Y=462.5397-0.23017 X$ & 0.98 & - \\
\hline \multicolumn{5}{|l|}{ Offal weight (g) } \\
\hline Full gizzard & Linear & $Y=54.253-0.03962 X$ & 0.95 & - \\
\hline Empty gizzard & Linear & $Y=41.3998-0.03346 X$ & 0.93 & - \\
\hline \multicolumn{5}{|l|}{ Offal yield (\%) } \\
\hline
\end{tabular}

LP - linear plateau; $\mathrm{R}^{2}$ - coefficient of determination.

Table 8 - Mean values of economic analysis parameters

\begin{tabular}{|c|c|c|c|c|c|c|c|c|}
\hline \multirow{2}{*}{ Phase (days) } & \multicolumn{5}{|c|}{ Pasta meal inclusion level $\left(\mathrm{g} \mathrm{kg}^{-1}\right)$} & \multirow{2}{*}{$\mathrm{SD}$} & \multirow{2}{*}{ P-value } & \multirow{2}{*}{$\mathrm{CV} \%$} \\
\hline & 0 & 100 & 200 & 300 & 400 & & & \\
\hline \multicolumn{9}{|c|}{ Feeding cost (US\$ per broiler) } \\
\hline 1 to 42 & 1.3377 & 1.2398 & 1.1229 & 1.0479 & 0.9793 & 0.019 & 0.0001 & 1.67 \\
\hline \multicolumn{9}{|c|}{ Feeding cost (US\$ per kg of broiler weight gain) } \\
\hline 1 to 42 & 0.5038 & 0.4901 & 0.4756 & 0.4628 & 0.4558 & 0.011 & 0.0001 & 2.31 \\
\hline \multicolumn{9}{|c|}{ Gross revenue (US\$ per broiler) } \\
\hline 1 to 21 & 0.8043 & 0.7910 & 0.7880 & 0.7713 & 0.7415 & 0.029 & 0.0003 & 3.78 \\
\hline 1 to 35 & 1.8493 & 1.7722 & 1.6437 & 1.6096 & 1.5321 & 0.047 & 0.0001 & 2.79 \\
\hline 1 to 42 & 2.4516 & 2.3358 & 2.1807 & 2.0905 & 1.9838 & 0.054 & 0.0001 & 2.46 \\
\hline \multicolumn{9}{|c|}{ Gross margin (US\$ per broiler) } \\
\hline \multicolumn{9}{|c|}{ Gross margin (US\$ per kg of broiler weight gain) } \\
\hline 1 to 21 & 0.4879 & 0.4937 & 0.5086 & 0.5188 & 0.5153 & 0.017 & 0.0003 & 3.28 \\
\hline 1 to 35 & 0.4325 & 0.4503 & 0.4671 & 0.4752 & 0.4778 & 0.012 & 0.0001 & 2.68 \\
\hline 1 to 42 & 0.4193 & 0.4329 & 0.4474 & 0.4602 & 0.4672 & 0.011 & 0.0001 & 2.48 \\
\hline
\end{tabular}

SD - standard deviation; CV - coefficient of variation. 
corroborates Ribeiro et al. (2002), who evaluated different corn particle sizes $(0.936,0.868,0.778,0.680,0.574$, and $0.337 \mu \mathrm{m})$ and noted that feed intake was lower for the diets with smaller particle sizes. This partly explains the decreased weight gain of birds in those phases. Furthermore, diets with pasta waste had less oil inclusion than the corn- and soybean-meal based diet, because the energy contained in that ingredient is higher than that of corn. This reduction in dietary fat content might have lowered the utilization of energy and nutrients from those diets in relation to control diet. In this regard, it is known that the energy efficiency of starch sources is lower than that of fat or oil sources. According to Braga and Baião (2001), the use of oil in feeds improves their palatability; reduces their dustiness, waste, and heat increments; provides a decreased rate of passage; and improves feed conversion.

The reduction observed in slaughter weight, hot and cold carcass weights, and in the weights of chest, drumstick, thigh, wings, and back was influenced by the weight of animals at 42 days. According to Silva et al. (2003), the final weight of broilers is positively correlated with hot and cold carcass weights and with primal cuts.

The decrease seen in weights of full and empty gizzard as well as in their respective yields is associated with the reduced mechanical work exerted by the muscle as influenced by the feed particle size. López and Baião (2004) affirmed this is because feeds containing smaller MGD have a higher rate of passage and elicit lower gizzard activity. Freitas et al. (2008) worked with increasing density levels $(\mathrm{g} / \mathrm{dL})$ obtained with the use of different quantities of cassava sweeping-waste meal in the diet $(0,75$, 150,225 , and $300 \mathrm{~g} \mathrm{~kg}^{-1}$ ) and concluded that higher diet density was a marked factor contributing to the reduction of gizzard weight and yield. As seen in the diets of the present experiment, their finding is explained by the fact that increasing density is also related to reduced particle sizes.

Pasta waste inclusion in the diets led to a decrease in feeding costs (US\$ per 1000 broilers and US\$ per $1000 \mathrm{~kg}$ of broiler weight gain), which is a consequence of the price of

Table 9 - Regression equations of the economic analysis

\begin{tabular}{|c|c|c|c|c|}
\hline Phase (days) & Effect & Equation & $\mathrm{R}^{2}$ & Level $\left(\mathrm{g} \mathrm{kg}^{-1}\right)$ \\
\hline & & Feeding cost (US\$ per 1000 broilers) & & \\
\hline 1 to 21 & LP & $\begin{array}{c}\mathrm{Y}=380.277-0.1394 \mathrm{X}_{0} \text { if } \mathrm{X}_{0} \leq 381.2 \\
\mathrm{Y}=327.148 \text { if } \mathrm{X}_{0}>381.2\end{array}$ & 0.99 & 381.2 \\
\hline 1 to 35 & LP & $\begin{array}{c}Y=975.754-0.70215 X_{0} \text { if } X_{0} \leq 337.6 \\
Y=738.726 \text { if } X_{0}>337.6\end{array}$ & 0.98 & 337.6 \\
\hline 1 to 42 & LP & $\begin{array}{c}Y=1,395.015-0.9862 X_{0} \text { if } X_{0} \leq 360.6 \\
Y=979.380 \text { if } X_{0}>360.6\end{array}$ & 0.99 & 360.6 \\
\hline 1 to 21 & LP & $\begin{array}{c}\mathrm{Y}=436.738-0.1036 \mathrm{X}_{0} \text { if } \mathrm{X}_{0} \leq 296.4 \\
\mathrm{Y}=406.00 \text { if } \mathrm{X}_{0}>296.4\end{array}$ & 0.97 & 296.4 \\
\hline 1 to 35 & LP & $\begin{array}{c}Y=490.431-0.17326 X_{0} \text { if } X_{0} \leq 253.3 \\
Y=446.5508 \text { if } X_{0}>253.3\end{array}$ & 0.99 & 253.3 \\
\hline 1 to 42 & LP & $\begin{array}{c}\mathrm{Y}=503.723-0.13754 \mathrm{X}_{0}^{0} \text { if } \mathrm{X}_{0} \leq 348.5 \\
\mathrm{Y}=455.7969 \text { if } \mathrm{X}_{0}>348.5\end{array}$ & 0.99 & 348.5 \\
\hline \multirow[t]{2}{*}{1 to 42} & Linear & $Y=2,444.677-1.180923 X$ & 0.99 & - \\
\hline & & Gross margin (US\$ per 1000 broilers) & & \\
\hline 1 to 35 & LP & $\begin{array}{c}\mathrm{Y}=936.34-0.35754 \mathrm{X}_{0} \text { if } \mathrm{X}_{0} \leq 228.5 \\
\mathrm{Y}=854.634 \text { if } \mathrm{X}_{0}>228.5\end{array}$ & 0.79 & 228.5 \\
\hline \multirow[t]{2}{*}{1 to 42} & LP & $\begin{array}{c}\mathrm{Y}=1,122.74-0.2902 \mathrm{X}_{0} \text { if } \mathrm{X}_{0} \leq 30.6 \\
\mathrm{Y}=1,113.88 \text { if } \mathrm{X}_{0}>30.6\end{array}$ & 0.99 & 30.6 \\
\hline & & Gross margin (US\$ per $1000 \mathrm{~kg}$ of broiler weight gain) & & \\
\hline \multirow[t]{2}{*}{1 to 21} & LP & $\mathrm{Y}=486.339+0.1036 \mathrm{X}_{0}$ if $\mathrm{X}_{0} \leq 296.4$ & & \\
\hline & & $\mathrm{Y}=517.046$ if $\mathrm{X}_{0}>296.4$ & 0.97 & 296.4 \\
\hline 1 to 35 & LP & $\begin{array}{c}Y=432.65+0.17326 X_{0} \text { if } X_{0} \leq 253.3 \\
Y=476.54 \text { if } X_{0}>253.3\end{array}$ & 0.99 & 253.3 \\
\hline
\end{tabular}

LP - linear plateau; $\mathrm{R}^{2}$ - coefficient of determination. 
this byproduct, whose cost of US\$ 0.13 per kg was adopted. As this byproduct was added to the diets, the levels of corn and oil, whose respective prices were US\$ 0.18 and 1.02 per kilogram, decreased. Soybean meal, whose sale price per kilogram was US\$ 0.40 , was also reduced, though at a lower intensity. Likewise, Agiang et al. (2004) tested diets containing cassava sweeping-waste meal and found a reduction of feed costs in relation to corn- and soybean meal-based diets.

However, the decreasing gross margin (US\$ per thousand broilers) in the periods of 1 to 35 and 1 to 42 days was due to the significant reduction of weight with the increasing levels of the byproduct added to broiler diets, which negatively affected the revenue. Although the feeding costs also declined with pasta waste inclusion, this reduction was not sufficient to offset the revenue losses. On the other hand, gross margin per thousand $\mathrm{kg}$ of weight gain increased, because the reference volume of $\mathrm{kg}$ used does not change. Therefore, gross revenue became fixed, and because the feeding costs are reduced with the inclusion of pasta waste, gross margin increased.

\section{Conclusions}

The energy contained in pasta waste is well utilized by broilers, as its apparent metabolizable energy and nitrogencorrected apparent metabolizable energy values are 3812 and $3616 \mathrm{kcal} \mathrm{kg}^{-1}$, respectively. However, in terms of performance, carcass characteristics, and economic viability, the inclusion of this byproduct at the levels of 100, 200,300, and $400 \mathrm{~g} \mathrm{~kg}^{-1}$ in diets is not a viable alternative, except for chicks in the pre-starter phase.

\section{Acknowledgments}

We would like to thank the Coordenação de Aperfeiçoamento de Pessoal de Nível Superior (CAPES), for granting the Master's degree grant to the first author, and REBRAS, for the supply of the ingredient.

\section{References}

ABIMAPI - Associação das Indústrias de Biscoitos, Massas Alimentícias e Pães \& Bolos Industrializados. 2017. Available at: $<$ https://www.abimapi.com.br>. Accessed on: Apr. 12, 2018.

Agiang, E. A.; Ayuk, A. A.; Nwelle, J. B. and Uzegbu, H. O. 2004. Performance of broiler fed diets with graded levels of cassava waste meal (CWM) as energy source. Journal of Agriculture and Food Science 2:13-19. https://doi.org/10.4314/jafs.v2i1.41607

Baghbanzhafar, S.; Afrouziyeh, M. and Zakeri, A. 2013. The effect of different levels of pasta by product with or without enzyme on performance of broiler chickens. European Journal of Experimental Biology 3:233-235.
Braga, J. P. and Baião, N. C. 2001. Suplementação lipídica no desempenho de aves em alta temperatura. Cadernos Técnicos de Veterinária e Zootecnia da UFMG: Avicultura - Nutrição e Manejo 31:23-28.

Compêndio Brasileiro de Alimentação Animal. 2017. Matériasprimas e ingredientes. 5. ed. Sindicato Nacional da Indústria de Alimentação Animal: SINDIRAÇÕES; ANFAL; CBNA, São Paulo. 204p.

Detmann, E.; Souza, M. A.; Valadares Filho, S. C.; Queiroz, A. C.; Berchielli, T. T.; Saliba, E. O. S.; Cabral, L. S.; Pina, D. S.; Ladeira, M. M. and Azevedo, J. A. G. 2012. Métodos para análise de alimentos. INCT - Ciência Animal 1. ed. Suprema, Visconde do Rio Branco. 14p.

Dexter, J. E.; Tchachuk, R. and Matsuo, R. R. 1984. Amino acid composition of spaghetti: effect of drying conditions on total and available lysine. Journal of Food Science 49:225-228. https://doi. $\operatorname{org} / 10.1111 / \mathrm{j} .1365-2621.1984 . t b 13713 . x$

Freitas, R. G. F.; Ludke, M. C. M. M.; Ludke, J. V.; Rabello, C. B. V.; Nascimento, G. R. and Barbosa, E. N. R. 2008. Inclusão da farinha de varredura de mandioca em rações de frangos de corte. Acta Scientiarum. Animal Sciences 30:155-163. https://doi.org/ 10.4025/actascianimsci.v30i2.4680

Gezeljeh, E. A. 2008. Determination of chemical composition and metabolizable energy of waste spaghetti and chickpea precleaning plants in different levels. Journal of Water and Soil Science 12:349-358.

Gheisari, A.; Bahadoran, R. and Tadayonfar, S. S. 2003. Determination of chemical composition and suitable levels of wheat feed screening and macaroni wastes in broiler chick diets. Journal of Water and Soil Science 7:161-170.

Lana, G. R. Q. 2000. Avicultura. Livraria e Editora Rural Ltda, Campinas. 268p.

Leoro, M. G. V. 2011. Macarrão instantâneo funcional obtido pelos processos de fritura convencional e a vácuo. Tese (D.Sc.). Universidade Estadual de Campinas, Campinas, SP.

Lima, T. S.; Rabello, C. B. V.; Lima, M. B.; Lopes, C. C.; Silva, D. P. V. and Arruda, E. M. F. 2012. Determinação do valor energético do resíduo de macarrão para frango de corte na fase pré-inicial. In: I Simpósio de Avicultura do Nordeste. Universidade Federal da Paraíba, João Pessoa.

Lopes, L. F. D.; Bum, D. V. and Gregorio, R. 2009. Identificação das perdas do processo produtivo na fabricação de massas alimentícias: um estudo baseado em sistema de custo. Ciência e Natura 31:35-56.

López, C. A. A. and Baião, N. C. 2004. Efeitos do tamanho da partícula e da forma física da ração sobre o desempenho, rendimento de carcaça e peso dos órgãos digestivos de frangos de corte. Arquivo Brasileiro de Medicina Veterinária e Zootecnia 56:214-221. https://doi.org/10.1590/S0102-09352004000200012

Matterson, L. D.; Potter, L. M. and Stutz, M. W. 1965. The metabolizable energy of feed ingredients for chickens. Agricultural Experimental Station Research Report 7:3-11.

Noni, I. and Pagani, M. A. 2010. Cooking properties and heat damage of dried pasta as influenced by raw material characteristics and processing conditions. Critical Reviews in Food Science and Nutrition 50:465-472. https://doi.org/10.1080/ 10408390802437154

Omole, A. J.; Okpeze, C. N.; Salako, R. A.; Obi, O. O. and Fayenuwo, J. O. 2013. Utilization of noodle waste as replacement for maize in the diet of broiler starter chickens. American Journal of Experimental Agriculture 3:1012-1019. https://doi.org/10.9734/ AJEA/2013/4617

Paes, J. P. S.; Freitas, H. J. and Cordeiro, M. B. 2015. Utilização de farelo de macarrão na alimentação de frango de corte de linhagem caipira. Enciclopédia Biosfera 11:1897-1902.

Ribeiro, A. M. L.; Magro, N. and Penz Jr., A. M. 2002. Granulometria do milho em rações de crescimento de frangos de corte e seu efeito 
no desempenho e metabolismo. Revista Brasileira de Ciência Avícola 4:(1):001-007. Available at: <http://dx.doi.org/10.1590/ S1516-635X2002000100006>. Accessed on: Feb. 02, 2018.

Rostagno, H. S.; Albino, L. F. T.; Donzele, J. L.; Gomes, P. C.; Oliveira, R. F.; Lopes, D. C.; Ferreira, A. S.; Barreto, S. L. and Euclides, R. F. 2011. Tabelas brasileiras para aves e suínos: composição de alimentos e exigências nutricionais. 3.ed. UFV, Viçosa, MG. 252p.

Rostagno, H. S.; Albino, L. F. T.; Donzele, J. L.; Gomes, P. C.; Oliveira, R. F.; Lopes, D. C.; Ferreira, A. S.; Barreto, S. L. and Euclides, R. F. 2017. Tabelas brasileiras para aves e suínos: composição de alimentos e exigências nutricionais. 4.ed. UFV, Viçosa, MG. 488p.

Silva, D. J. and Queiroz, A. C. 2002. Análises de alimentos: métodos químicos e biológicos 3.ed. Editora UFV, Viçosa, MG. 235p.

Silva, J. H. V.; Albino, L. F. T. and Nascimento, A. H. 2003. Estimativas da composição anatômica de carcaça de frangos de corte com base no nível de proteína da ração e peso da carcaça. Revista Brasileira de Zootecnia 32:344-352. https://doi.org/ 10.1590/S1516-35982003000200013
Silva, E. A.; Albino, L. F. T.; Rostagno, H. S.; Ribeiro Jr., V.; Vieira, R. A.; Campos, A. M. A. and Messias, R. K. G. 2012a. Chemical composition and metabolizable energy values of feedstuffs for broiler chickens. Revista Brasileira de Zootecnia 41:648-654. https://doi.org/10.1590/S1516-35982012000300026

Silva, E. A.; Albino, L. F. T.; Rostagno, H. S.; Vieira, R. A.; Ribeiro Jr., V.; Campos, A. M. A. and Pereira, J. P. L. 2012b. Determination of true digestible amino acids of feedstuffs utilizing cecectomized roosters. Revista Brasileira de Zootecnia 41:2070-2078. https:// doi.org/10.1590/S1516-35982012000900015

Silva, T. R. M.; Andrade, M. L. S.; Chung, S. and Bicudo, A. J. A. 2014. Substituição parcial do milho pelo resíduo de macarrão em dietas para tilápia-do-Nilo. Boletim do Instituto de Pesca 40:669-676.

Zanotto, D. L.; Cunha Junior, A.; Ludke, J. V. and Coldebella, A. 2016 Análise de granulometria de milho moído. Embrapa Suínos e Aves, Concórdia. 5p. (Embrapa Suínos e Aves. Comunicado Técnico, 536). Available at: <http://www.infoteca.cnptia.embrapa. br/infoteca/bitstream/doc/1062014/1/Cot536.pdf $>$. Accessed on: Mar. 12, 2018. 